\title{
LONG-TERM DYNAMICS OF FUNCTIONAL CONDITION OF THE HEART IN PATIENTS WITH BRONCHIAL ASTHMA DEPENDING ON THE SEVERITY AND CONTROLLABILITY OF THE DISEASE
}

\author{
ДОВГОТРИВАЛА ДИНАМІКА ФУНКЦІОНАЛЬНОГО \\ СТАНУ СЕРЦЯ У ХВОРИХ НА БРОНХІАЛЬНУ АСТМУ \\ В ЗАЛЕЖНОСТІ ВІД СТУПЕНЯ ТЯЖКОСТІ \\ ТА КОНТРОЛЬОВАНОСТІ ПЕРЕБІГУ ЗАХВОРЮВАННЯ
}

\author{
Yurii Feshchenko ${ }^{1}$ \\ Lesia Kuryk $^{2}$
}

DOI: https://doi.org/10.30525/978-9934-588-15-0-73

\begin{abstract}
The aim of this work was to establish the functional state of the heart and its long-term dynamics in patients with bronchial asthma, depending on the severity and controllability of the disease. Materials and methods. The study involved 480 patients with BA of varying severity and controllability of the disease. There were 92 patients with mild asthma, with controlled moderate asthma -81 patients, with uncontrolled moderate asthma 69 patients, with severe partially controlled asthma - 95 patients, with severe uncontrolled asthma -43 patients. The survey was conducted according to the planned schedule for the first, seventh and tenth year. When analyzing 24-hour ECG monitoring, heart rate (HR) and heart rhythm disturbances were assessed. With rhythm disturbances, ventricular, supraventricular extrasystoles, atrial and sinus arrhythmias were distinguished. The heart rate was distributed on bradycardia and tachycardia with the determination of the time of day of their registration. The work was carried out with state funds. Results and conclusions. Summing up the study, it was found that the severity deter-
\end{abstract}

\footnotetext{
${ }^{1}$ Academician of the National Academy of Medical Sciences of Ukraine, Doctor of Medical Sciences, Professor, Head of Pulmonology Department, SO «National Institute Phthysiology and Pulmonology named after F.G. Yanovsky of the National Academy of Medical Sciences of Ukraine», Ukraine

${ }^{2}$ Candidate of Medical Sciences, Senior Research Worker Pulmonology Department, SO «National Institute Phthysiology and pulmonology named after F. G. Yanovsky of the National Academy of Medical Sciences of Ukraine», Ukraine
} 
mines the functional state of the heart, and the control of asthma affects the temporary maladaptation of the heart functional not only through the pathogenesis of the disease itself (constant bronchospasm, the presence of attacks, etc.), but also through the negative impact of the resulting basic therapy of the disease (glucocorticosteroids, bronchodilators). With a mild course of asthma, no significant violations of the functional state of the heart were found, which indicates the complete implementation of the adaptation mechanisms of the cardiovascular system to ensure daily activity. In moderate asthma, regardless of the control of the course of the disease, the first maladaptive mechanisms are triggered - an increase and diurnal fluctuation of systolic blood pressure under normal diastolic pressure, an increase in heart rate (both day and night), increased ventricular extrasystoles, bigeminia and tachycardia at night. However, all this with a controlled course of $\mathrm{AD}$ remains stable in time, without significant deterioration, while with an uncontrolled $\mathrm{AD}$, the disadaptation of the functional state of the heart increases significantly. In severe asthma, disadaptation mechanisms fully occur in the functional state of the heart: in response to the usual daily load, a significant increase in the value of systolic and diastolic blood pressure, a significant percentage of fluctuations in excess of the age norm of systolic and diastolic blood pressure, a high percentage of tachycardia, ventricular extrasystoles (with bigeminia). And while with a partially controlled severe course, all of the above changes are more or less stable over time, then with an uncontrolled severe course, significant progression of pathological changes in the functional state of the heart is noted.

\section{1. Вступ}

Бронхіальна астма,як комплексна патологія, не може розглядатися без урахування кардіореспіраторної адаптації, яка спрямована на оптимізацію гомеостазу при виконанні фізичного навантаження, адже саме від ступеня ії компенсаторних можливостей залежать вітальний і трудовий прогнози для пацієнтів [1]. Функціональний стан серцево-судинної системи, її адаптація до зміни кардіореспіраторного навантаження, досить часто стає місцем, де реалізується перехід адаптації в пошкодження. 3 іншого боку, система кровообігу безпосередньо страждає від порушення вентиляції, що є основним патогенним чинником БА. Крім того, такі хворі постійно змушені приймати базисні і симптоматичні препарати (глюкокортикостероїди, бронхолітики три- 
валої діі). Гіперфункція міокарда спостерігається вже на ранніх стадіях астми за рахунок перебудови гемодинаміки по гіперкінетичному типу, компенсаторного підвищення артеріального тиску, збільшення частоти серцевих скорочень (ЧСС), ударного об'єму (УО), хвилинного об'єму кровообігу (ХОК). Бронхіальна обструкція призводить до альвеолярної гіповентиляції, наслідком якої $є$ альвеолярна гіпоксія. Порушення внутрішньокардіальної гемодинаміки у хворих на БА залежить від вираженості обструктивного синдрому і відбувається по стадіям, паралельно зі змінами в легенях та гемодинаміки малого кола кровообігу (МКК). На ранніх стадіях БА гіпоксія носить незначний характер і виникає тільки при фізичному навантаженні. При обтяженні перебігу БА розвивається транзиторна легенева гіпертензія і гіперфункція міокарду, як компенсаторна реакція, спрямована на попередження тривалої гіпоксії та ушкодження тканин [2]. Надалі, виражена і тривала гіпоксія у хворих на бронхіальну астму веде до стабілізації легеневої гіпертензії і зриву компенсаторної можливості міокарду із негативним зсувом енергетичного балансу, що і $є$ метаболічною основою розвитку міокардіодистрофії. При прогресуванні легеневих порушень гіперкінетичний варіант переходить в еукінетичний, а в подальшому в гіпокінетичний тип центральної гемодинаміки. Однак формування гіпокінетичного типу гемодинаміки можливе вже на ранніх етапах БА. Еукінетичний тип кровообігу характеризується зниженою величиною ударного об'єму (УО), збільшеною частотою серцевих скорочень (ЧСС) та незміненим хвилинним об'ємом крові (ХОК). При дослідженні легеневої гемодинаміки виявляється не значна легенева гіпертензія і перевантаження правого шлуночка, що пов'язано із прогресуючим зростанням легеневого судинного опору. Відзначається зниження кровонаповнення легенів. Падіння УО на тлі підвищеного загального периферичного опору (ЗПО) у хворого БА $є$ компенсаторно-пристосувальною реакцією, що зменшує перевантаження малого кола кровообігу (МКК). Підтримання адекватного кровопостачання забезпечується шляхом рефлекторного перерозподілу органного кровотоку і підтримки за рахунок збільшення частоти серцевих скорочень. Для гіпокінетичному типу гемодинаміки характерне зниження ХОК, збільшення ЗПО, зменшення скоротливої здатності міокарда. У цієї категорії пацієнтів діагностується виражена легенева 
гіпертензія, із ознаками перевантаження правого шлуночка і високим опором судинного русла кровотоку та розвитком дистрофічних змін міокарду. Вплив артеріальної гіпоксемії у хворих на БА призводить до порушення не тільки систолічної функції міокарда правого шлуночка (ПШ), але може негативно впливати на діастолічну функцію із розвитком феномену дефект - діастоли - поступового зникнення ефективного розслаблення серцевого м'яза при рО2 менше 50 мм рт. ст.

Проте на думку ряду авторів найбільш ранніми змінами зі сторони ССС $є$ порушення функції лівого передсердя із збільшенням його об'єму і розвиток діастолічної дисфункції лівого шлуночка (ЛШ ), а діастолічна дисфункція ПШ розвивається пізніше, ніж ЛШ, і виявляється лише при тяжкому перебігу БА [3]. Характер змін гемодінаміки під час нападу ядухи залежить від функціональних змін міокарду. Збільшення ХОК за рахунок УО серця та зростання частоти серцевих скорочень із зменшенням загального периферичного і легеневого артеріального опору свідчить про хорошу адаптаційну здатність серця. Підтримка об'єму крові за рахунок зростання частоти серцевих скорочень при незмінному чи зменшеному УО серця супроводжується зниженням потужності міокарда, зростанням тиску в правому шлуночку, що є вже проявом серцевої недостатності. Таким чином, зміни гемодинаміки у хворих БА відрізняються стадійністю. При достатніх компенсаторних можливостях серцево-судинної системи гіперфункція серця супроводжується розвитком гіперкінетичного типу кровообігу. Збільшення ХОК покращує ефективність вентиляції, підвищує коефіцієнт використання кисню. По мірі прогресування БА відзначається зниження УО та ХОК. Це пов'язано із падінням скорочувальної здатності міокарда, а також із розвитком емфіземи легень, що приводить до збільшення внутрішньогрудного тиску із наступним здавленням великих судин, що переносять кров до серця.

Разом $з$ тим, як саме змінюється функціональний стан серця в залежності від контрольованості перебігу БА вивчені недостатньо $€$ лише нечисленні і часто вельми суперечливі літературні відомості, в яких фрагметарно оцінюються параметри цієї системи, що і стало метою проведеної роботи - установити функціональний стан серця, його довготривалу динаміку у хворих на бронхіальну астму в залежності від ступеня тяжкості та контрольованості перебігу захворювання при стандартному базисному лікуванні. 


\section{2. Матеріали та методи}

У дослідженні приймало участь 480 хворих на БА різного ступеня тяжкості та контрольованості перебігу БА. Із них із легким ступенем тяжкості БА було 92, із контрольованим середнім ступенем тяжкості БА 81, із не контрольованим середнім ступенем тяжкості БА - 69, із тяжким частково контрольованим перебігом БА - 95, із тяжким не контрольованим перебігом БА - 43. Обстеження проводилось згідно запланованого графіку на перший рік, на сьомий та десятий рік [4-8].

Функціональний стан серця вивчали за допомогою добового холтерівського моніторингу проведення ЕКГ $[11 ; 12 ; 13]$. Добове вимірювання виконувалось за допомогою холтерівської системи ЕКГ з інфрачервоним інтерфейсом «ЕС-3Н/AРВ» (Венгрія) в «звичайних» умовах життя пацієнта, в яких його поведінка не обмежувалась стінами лікувального закладу або рамками спеціального режиму. При аналізі добового моніторування ЕКГ оцінювались частота серцевих скорочень (ЧСС) та порушення ритму серця. При порушеннях ритму відзначались шлуночкові, суправентрикулярні екстрасистоли, миготлива та синусова аритмії протягом доби. Частота серцевих скорочень розподілялась на брадикардію та тахікардію з визначенням часу доби їх реєстрації. Статистична обробка матеріалу проводилася за допомогою ліцензійних програмних продуктів, які входять у пакет Microsoft Office Professional 2000, ліцензія Russian Academic OPEN NO LEVEL № 17016297 на персональному комп'ютері IBM Atlon у програмі Excel $[14 ; 15]$. Робота виконана державним коштом.

\section{3. Функціональний стан серця при легкому перебігу бронхіальної астми}

Аналіз отриманих результатів функціонального стану серця показав, що у даної категорії хворих немає достовірної різниці у функціональному стані серця порівняно із групою здорових осіб і дана закономірність $є$ стабільною у часі - достовірної динаміки у показниках всередині групи та у порівнянні із здоровими протягом семи та десяти років спостереження не відбувалось (табл. 1).

Достовірної відмінності у порівнянні із групою здорових осіб не було.

4. Функціональний стан серця при перебігу бронхіальної астми середнього ступеня тяжкості в залежності від контрольованості перебігу захворювання. 
Таблиця 1

Результати добового моніторингу ЕКГ у хворих на БА із легким перебігом захворювання (M $\pm \mathbf{m})$

\begin{tabular}{|l|c|c|c|c|}
\hline \multicolumn{1}{|c|}{ Показники } & 3дорові & Візит I & Візит III & Візит IV \\
\hline Мінімальна ЧСС за добу & $72,3 \pm 3,3$ & $60,9 \pm 3,1$ & $54,1 \pm 2,0$ & $56,0 \pm 1,0$ \\
\hline Середня ЧСС за добу & $73,5 \pm 2,9$ & $72,0 \pm 2,3$ & $71,1 \pm 2,9$ & $72,6 \pm 1,9$ \\
\hline Максимальна ЧСС за добу & $89,1 \pm 3,3$ & $88,4 \pm 3,3$ & $83,6 \pm 3,2$ & $81,5 \pm 2,8$ \\
\hline Мінімальна ЧСС за день & $65,2 \pm 3,4$ & $62,7 \pm 3,1$ & $61,7 \pm 2,7$ & $60,8 \pm 2,0$ \\
\hline Середня ЧСС за день & $77,7 \pm 3,0$ & $74,7 \pm 2,3$ & $78,1 \pm 3,0$ & $76,2 \pm 2,4$ \\
\hline Максимальна ЧСС за день & $99,1 \pm 3,3$ & $94,4 \pm 3,3$ & $95,6 \pm 3,2$ & $97,7 \pm 2,5$ \\
\hline Мінімальна ЧСС за ніч & $68,9 \pm 3,4$ & $62,8 \pm 3,2$ & $63,6 \pm 2,1$ & $67,4 \pm 1,0$ \\
\hline Середня ЧСС за ніч & $63,7 \pm 2,8$ & $65,3 \pm 2,9$ & $61,3 \pm 2,6$ & $63,0 \pm 1,8$ \\
\hline Максимальна ЧСС за ніч & $73,5 \pm 2,7$ & $72,9 \pm 2,9$ & $70,2 \pm 2,8$ & $72,2 \pm 3,5$ \\
\hline \multicolumn{4}{|c|}{ Шлуночкові результати } \\
\hline Скорочення, абс. результат & $72,5 \pm 6,5$ & $82,4 \pm 8,5$ & $72,9 \pm 5,1$ & $75,1 \pm 3,7$ \\
\hline Скорочення, \% нічних & $18,7 \pm 4,3$ & $11,7 \pm 6,9$ & $11,6 \pm 3,7$ & $9,7 \pm 3,1$ \\
\hline $\begin{array}{l}\text { Шлуночкові екстрасистоли, } \\
\text { абс. результат }\end{array}$ & $12,8 \pm 0,6$ & $15,6 \pm 1,4$ & $14,4 \pm 2,6$ & $12,3 \pm 1,7$ \\
\hline $\begin{array}{l}\text { Шлуночкові екстрасистоли, } \\
\text { \% нічних }\end{array}$ & $10,1 \pm 2,3$ & $10,5 \pm 6,5$ & $11,2 \pm 3,7$ & $9,5 \pm 3,1$ \\
\hline Парні, абс. результат & $2,5 \pm 0,2$ & $3,4 \pm 4,0$ & $2,0 \pm 0,9$ & $1,2 \pm 0,1$ \\
\hline Парні, \% нічних & $3,1 \pm 0,8$ & $3,9 \pm 1,8$ & $5,4 \pm 2,3$ & $0,0 \pm 0,0$ \\
\hline Пробіжки, абс. результат & $0,2 \pm 0,1$ & $0,1 \pm 0,1$ & $0,3 \pm 0,2$ & $0,1 \pm 0,1$ \\
\hline Пробіжки, \% нічних & $0,0 \pm 0,0$ & $5,0 \pm 5,1$ & $7,9 \pm 4,2$ & $2,0 \pm 0,2$ \\
\hline Бігемінія, абс. результат & $0,5 \pm 0,0$ & $5,4 \pm 5,1$ & $2,7 \pm 1,0$ & $2,3 \pm 1,0$ \\
\hline Бігемінія, \% нічних & $1,3 \pm 0,1$ & $1,5 \pm 0,3$ & $1,4 \pm 0,2$ & $1,6 \pm 0,6$ \\
\hline Тахікардія,абс. результат & $0,0 \pm 0,0$ & $0,0 \pm 0,0$ & $0,0 \pm 0,0$ & $0,1 \pm 0,1$ \\
\hline Тахікардія, \% нічних & $0,0 \pm 0,0$ & $0,0 \pm 0,0$ & $0,0 \pm 0,0$ & $0,0 \pm 0,0$ \\
\hline
\end{tabular}

У групі хворих із контрольованим перебігом БА середнього ступеня тяжкості протягом усього періоду спостереження спостерігалась достовірна різниця порівняно із групою здорових у показниках загальних скорочень: мінімальної та максимальної ЧСС за добу, мінімальної ЧСС за ніч, а також збільшення шлуночкових екстрасистол, серед них парних скорочень за добу та ніч із наявністю бігемінії (особливо у нічний час), що свідчить про порушення серцевого ритму не лише у денний час, але і вночі (табл. 2). Достовірної динаміки в оцінюваних показниках всередині групи протягом семи - та десятирічного періоду спостереження не встановлено. 
Таблиця 2

Результати добового моніторингу ЕКГ у хворих на БА із контрольованим перебігом середнього ступеня тяжкості (M $\pm \mathbf{m})$

\begin{tabular}{|c|c|c|c|c|}
\hline Показники & Здорові & Візит I & Візит III & Візит IV \\
\hline 1 & 2 & 3 & 4 & 5 \\
\hline Мінімальна ЧСС за добу & $72,3 \pm 3,3$ & $59,5 \pm 3,3^{*}$ & $56,0 \pm 1,0^{\star}$ & $60,9 \pm 3,1$ \\
\hline Середня ЧСС за добу & $73,5 \pm 2,9$ & $72,3 \pm 2,9$ & $72,6 \pm 1,9$ & $72,0 \pm 2,3$ \\
\hline Максимальна ЧСС за добу & $89,1 \pm 3,3$ & $91,1 \pm 3,3$ & $100,5 \pm 2,8^{\bullet}$ & $94,4 \pm 3,3$ \\
\hline Мінімальна ЧСС за день & $65,2 \pm 3,4$ & $64,2 \pm 3,4$ & $60,1 \pm 2,0$ & $62,7 \pm 3,1$ \\
\hline Середня ЧСС за день & $77,7 \pm 3,0$ & $74,7 \pm 2,3$ & $75,1 \pm 3,0$ & $76,2 \pm 2,4$ \\
\hline Максимальна ЧСС за день & $99,1 \pm 3,3$ & $94,4 \pm 3,3$ & $93,6 \pm 3,2$ & $98,7 \pm 2,5$ \\
\hline Мінімальна ЧСС за ніч & $68,9 \pm 3,4$ & $62,8 \pm 3,2$ & $54,6 \pm 2,1^{\bullet}$ & $57,4 \pm 1,0^{\star}$ \\
\hline Середня ЧСС за ніч & $63,7 \pm 2,8$ & $66,3 \pm 2,9$ & $61,3 \pm 2,6$ & $65,0 \pm 1,8$ \\
\hline Максимальна ЧСС за ніч & $73,5 \pm 2,7$ & $72,9 \pm 2,9$ & $70,2 \pm 2,8$ & $79,2 \pm 3,5$ \\
\hline \multicolumn{5}{|c|}{ Шлуночкові результати } \\
\hline Скорочення, абс. результат & $72,5 \pm 96,5$ & $92,9 \pm 5,1^{\bullet}$ & $167,4 \pm 7,5^{\star}$ & $173,5 \pm 6,5^{*}$ \\
\hline Скорочення, \% нічних & $18,7 \pm 4,3$ & $11,6 \pm 3,7$ & $21,7 \pm 6,9$ & $18,7 \pm 4,3$ \\
\hline $\begin{array}{l}\text { Шлуночкові екстрасистоли, } \\
\text { абс результат }\end{array}$ & $12,8 \pm 0,6$ & $110,4 \pm 8,6^{*}$ & $104,6 \pm 8,4^{*}$ & $102,8 \pm 8,6^{*}$ \\
\hline $\begin{array}{l}\text { Шлуночкові екстрасистоли, } \\
\text { \% нічних }\end{array}$ & $10,1 \pm 2,3$ & $21,2 \pm 3,7^{\bullet}$ & $25,5 \pm 4,5^{\bullet}$ & $23,1 \pm 2,3^{\bullet}$ \\
\hline Парні, абс. результат & $2,5 \pm 0,2$ & $2,0 \pm 0,9$ & $5,4 \pm 4,0$ & $2,5 \pm 0,2$ \\
\hline Парні, \% нічних & $3,1 \pm 0,8$ & $15,4 \pm 4,3^{*}$ & $13,9 \pm 3,8^{\bullet}$ & $13,1 \pm 0,8$ \\
\hline Пробіжки, абс. результат & $0,2 \pm 0,1$ & $0,3 \pm 0,2$ & $0,1 \pm 0,1$ & $0,2 \pm 0,1$ \\
\hline Пробіжки, \% нічних & $0,0 \pm 0,0$ & $7,5 \pm 2,2$ & $5,0 \pm 2,1^{\bullet}$ & $5,0 \pm 0,2$ \\
\hline Бігемінія, абс. результат & $0,5 \pm 0,0$ & $5,7 \pm 1,0^{4}$ & $5,4 \pm 0,1^{\star}$ & $5,5 \pm 0,0^{\star}$ \\
\hline Бігемінія, \% нічних & $1,3 \pm 0,1$ & $6,4 \pm 3,2$ & $4,5 \pm 2,3^{\star}$ & $2,3 \pm 0,1^{\star}$ \\
\hline Тахікардія, абс. результат & $0,0 \pm 0,0$ & $0,0 \pm 0,0$ & $0,0 \pm 0,0$ & $0,0 \pm 0,0$ \\
\hline Тахікардія, \% нічних & $0,0 \pm 0,0$ & $0,0 \pm 0,0$ & $0,0 \pm 0,0$ & $0,0 \pm 0,0$ \\
\hline
\end{tabular}

Примітка. - різницю показника із групою здорових статистично доведено $(\mathrm{p}<0,05)$.

При не контрольованому перебігу БА середнього ступеня тяжкості також протягом усього періоду спостереження спостерігалась достовірна різниця порівняно із групою здорових у відсотку випадків шлуночкових ектопій. У групі із часом відбувалась поступова декомпенсація функціонального стану серця, що підтверджувалось достовірним підвищенням відсотку шлуночкових та суправентрикулярних ектопій на 
десятий рік спостереження, основною причиною чого були персистуючим бронхоспазм, часті загострення, частий прийом інгаляційних та системних глюкокортикостероїдів та надмірне користування бета-агоністами короткої дії (постійна потреба через астма-симптоми) (табл. 3).

Таблиця 3

\section{Результати добового моніторингу ЕКГ у хворих на БА} із не контрольованим перебігом середнього ступеня тяжкості (M $\pm \mathbf{m})$

\begin{tabular}{|c|c|c|c|c|}
\hline Показники & Здорові & Вiзит I & Візит III & Візит IV \\
\hline 1 & 2 & 3 & 4 & 5 \\
\hline Мінімальна ЧСС за добу & $72,3 \pm 3,3$ & $58,8 \pm 3,2$ & $60,4 \pm 3,3^{\star}$ & $57,9 \pm 3,1$ \\
\hline Середня ЧСС за добу & $73,5 \pm 2,9$ & $72,8 \pm 2,5$ & $72,9 \pm 1,8$ & $71,7 \pm 1,8$ \\
\hline Максимальна ЧСС за добу & $89,1 \pm 3,3$ & $95,1 \pm 3,2$ & $102,4 \pm 2,7^{\star}$ & $105,6 \pm 3,1^{\bullet} \#$ \\
\hline Мінімальна ЧСС за день & $65,2 \pm 3,4$ & $64,8 \pm 3,2$ & $61,2 \pm 2,2$ & $63,7 \pm 2,1$ \\
\hline Середня ЧСС за день & $77,7 \pm 3,0$ & $72,3 \pm 2,1$ & $73,1 \pm 2,0$ & $72,2 \pm 2,4$ \\
\hline Максимальна ЧСС за день & $99,1 \pm 3,3$ & $102,4 \pm 3,5$ & $103,8 \pm 3,5$ & $114,7 \pm 2,6 \#$ \\
\hline Мінімальна ЧСС за ніч & $68,9 \pm 3,4$ & $61,9 \pm 3,2$ & $77,6 \pm 2,2$ & $78,4 \pm 1,8 \bullet \#$ \\
\hline Середня ЧСС за ніч & $63,7 \pm 2,8$ & $63,8 \pm 2,1$ & $73,1 \pm 2,3$ & $74,2 \pm 2,6^{\bullet} \#$ \\
\hline Максимальна ЧСС за ніч & $73,5 \pm 2,7$ & $78,3 \pm 2,6$ & $76,4 \pm 2,4$ & $79,8 \pm 3,2$ \\
\hline \multicolumn{5}{|c|}{ Шлуночкові результати } \\
\hline Скорочення, абс. результат & $72,5 \pm 96,5$ & $92,9 \pm 5,1^{\bullet}$ & $167,4 \pm 7,5^{\bullet}$ & $173,5 \pm 6,5^{\bullet} \#$ \\
\hline Скорочення, \% нічних & $18,7 \pm 4,3$ & $22,8 \pm 3,7$ & $24,6 \pm 6,1^{\star}$ & $32,4 \pm 2,3 * \#$ \\
\hline $\begin{array}{l}\text { Шлуночкові екстрасистоли, } \\
\text { абс результат }\end{array}$ & $12,8 \pm 0,6$ & $89,3 \pm 8,6^{\star}$ & $101,6 \pm 8,1^{\star}$ & $104,2 \pm 8,6^{\bullet} \#$ \\
\hline $\begin{array}{l}\text { Шлуночкові екстрасистоли, } \\
\text { \% нічних }\end{array}$ & $10,1 \pm 2,3$ & $31,4 \pm 3,7^{\star}$ & $45,5 \pm 4,5^{\bullet} \#$ & $43,1 \pm 2,3^{\star} \#$ \\
\hline Парні, абс. результат & $2,5 \pm 0,2$ & $3,1 \pm 0,9$ & $6,3 \pm 2,2 \bullet \#$ & $7,5 \pm 1,8 * \#$ \\
\hline Парні, \% нічних & $3,1 \pm 0,8$ & $18,2 \pm 2,3^{\star}$ & $19,1 \pm 3,2$ & $16,5 \pm 1,8$ \\
\hline Пробіжки, абс. результат & $0,2 \pm 0,1$ & $7,6 \pm 0,2$ & $8,1 \pm 0,1$ & $8,2 \pm 0,1$ \\
\hline Пробіжки, \% нічних & $0,0 \pm 0,0$ & $5,5 \pm 2,2$ & $5,3 \pm 2,1^{\bullet}$ & $5,4 \pm 0,2^{\bullet}$ \\
\hline Бігемінія, абс. результат & $0,5 \pm 0,0$ & $15,9 \pm 1,0^{\star}$ & $15,2 \pm 0,1^{\bullet}$ & $17,5 \pm 0,0^{*}$ \\
\hline Бігемінія, \% нічних & $1,3 \pm 0,1$ & $8,4 \pm 3,2^{\star}$ & $8,5 \pm 2,1^{\bullet}$ & $8,3 \pm 0,1^{\star}$ \\
\hline Тахікардія, абс. результат & $0,0 \pm 0,0$ & $22,0 \pm 1,2$ & $23,8 \pm 0,8$ & $22,3 \pm 0,2$ \\
\hline Тахікардія, \% нічних & $0,0 \pm 0,0$ & $10,0 \pm 0,1$ & $12,3 \pm 0,1$ & $12,0 \pm 0,1$ \\
\hline
\end{tabular}

Примітка 1. - різницю показника із групою здорових статистично доведено $(\mathrm{p}<0,05)$. Примітка 2. \#- різницю показника із початком спостереження статистично доведено $(\mathrm{p}<0,05)$. 


\section{5. Функціональний стан серця при тяжкому перебігу бронхіальної астми в залежності від контрольованості перебігу захворювання}

При тяжкому частково контрольованому перебігу БА достовірна різниця порівняно із групою здорових спостерігалась протягом усього періоду спостереження, залишаючись без динаміки всередині групи (табл. 4). Через 10 років спостереження зберігалась достовірна різниця в усіх оцінюваних показниках порівняно із групою здорових, проте достовірного погіршення у оцінюваних показниках функціонального стану серця не відбувалось.

При оцінюванні серцевого ритму у групі через на десятому році спостереження достовірних змін у порівнянні із початком спостереження не було. Зберігалась досить значна кількість шлуночкових екстрасистол у групі із переважанням бігемінії (із них парні бігемініі), а також спостерігалась тахікардія (навіть і вночі).

Різницю показника із початком спостереження статистично не встановлено.

При тяжкому не контрольованому перебігу бронхіальної астми спостерігалась ідентична картина у функціональному стані серця на початку спостереження, як і при контрольованому перебігу захворювання. При оцінюванні серцевого ритму у групі із тяжким не контрольованим перебігом були достовірно збільшені показники мінімального, середнього та максимального ЧСС за день, ніч, добу, шлуночкові результати показували значну кількість шлуночкових екстрасистол у групі із переважанням бігемінії (із них парні бігемінії), а також спостерігалась тахікардія (в тому числі і нічна) (табл. 5).

При оцінюванні серцевого ритму у групі через 10 років спостереження достовірні зміни були у всіх показниках порівняно із початком спостереження. Достовірно зростали мінімальне, середнє та максимальне ЧСС за день, ніч, добу, шлуночкові результати демонстрували велику кількість шлуночкових екстрасистол із переважанням бігемінії (із них парні бігемінії) та тахікардії (навіть і вночі).

\section{6. Висновки}

Підводячи підсумок проведеного дослідження, було встановлено, що ступінь тяжкості визначає функціональний стан серця, а контро- 
Таблиця 4

Результати добового моніторингу ЕКГ у хворих на БА із тяжким частково контрольованим перебігом (M $\pm \mathbf{m})$

\begin{tabular}{|c|c|c|c|c|}
\hline Показники & Здорові & Візит I & Візит III & Візит IV \\
\hline 1 & 2 & 3 & 4 & 5 \\
\hline Мінімальна ЧСС за добу & $72,3 \pm 3,3$ & $78,3 \pm 3,1^{\bullet}$ & $77,7 \pm 3,3^{\circ}$ & $77,9 \pm 3,2$ \\
\hline Середня ЧСС за добу & $73,5 \pm 2,9$ & $77,6 \pm 2,4$ & $80,6 \pm 2,2$ & $80,2 \pm 1,7$ \\
\hline Максимальна ЧСС за добу & $89,1 \pm 3,3$ & $97,4 \pm 3,1$ & $99,2 \pm 2,6^{*}$ & $98,5 \pm 3,2^{\bullet}$ \\
\hline Мінімальна ЧСС за день & $65,2 \pm 3,4$ & $68,2 \pm 3,1$ & $65,7 \pm 2,1$ & $65,8 \pm 2,5$ \\
\hline Середня ЧСС за день & $77,7 \pm 3,0$ & $71,8 \pm 2,2$ & $72,3 \pm 2,1$ & $72,1 \pm 2,1$ \\
\hline Максимальна ЧСС за день & $99,1 \pm 3,3$ & $101,3 \pm 3,1$ & $100,2 \pm 3,2$ & $108,5 \pm 2,4$ \\
\hline Мінімальна ЧСС за ніч & $68,9 \pm 3,4$ & $61,7 \pm 3,1$ & $67,8 \pm 2,3^{\bullet}$ & $71,4 \pm 1,4^{\star}$ \\
\hline Середня ЧСС за ніч & $63,7 \pm 2,8$ & $64,1 \pm 2,2$ & $70,2 \pm 2,1$ & $71,3 \pm 2,3^{*}$ \\
\hline Максимальна ЧСС за ніч & $73,5 \pm 2,7$ & $75,4 \pm 2,5$ & $76,8 \pm 2,4$ & $78,8 \pm 3,5$ \\
\hline \multicolumn{5}{|c|}{ Шлуночкові результати } \\
\hline Скорочення, абс. результат & $72,5 \pm 96,5$ & $145,4 \pm 5,2^{*}$ & $163,2 \pm 7,5^{\star}$ & $163,5 \pm 6,3^{*}$ \\
\hline Скорочення, \% нічних & $18,7 \pm 4,3$ & $28,7 \pm 3,7$ & $25,3 \pm 6,2^{*}$ & $30,4 \pm 2,1^{\bullet}$ \\
\hline $\begin{array}{l}\text { Шлуночкові екстрасистоли, } \\
\text { абс результат }\end{array}$ & $12,8 \pm 0,6$ & $88,1 \pm 8,6^{\bullet}$ & $98,4 \pm 8,2$ & $99,2 \pm 8,3^{*}$ \\
\hline $\begin{array}{l}\text { Шлуночкові екстрасистоли, } \\
\text { \% нічних }\end{array}$ & $10,1 \pm 2,3$ & $32,5 \pm 3,6^{\bullet}$ & $42,3 \pm 4,5^{\bullet}$ & $43,2 \pm 2,1^{\bullet}$ \\
\hline Парні, абс. результат & $2,5 \pm 0,2$ & $3,8 \pm 0,9$ & $4,3 \pm 2,2$ & $4,5 \pm 1,8^{*}$ \\
\hline Парні, \% нічних & $3,1 \pm 0,8$ & $20,7 \pm 2,5^{\circ}$ & $29,0 \pm 3,2^{\bullet}$ & $26,5 \pm 1,9$ \\
\hline Пробіжки, абс. результат & $0,2 \pm 0,1$ & $17,6 \pm 0,2$ & $18,3 \pm 0,1$ & $18,2 \pm 0,8$ \\
\hline Пробіжки, \% нічних & $0,0 \pm 0,0$ & $15,7 \pm 2,3^{\bullet}$ & $15,8 \pm 2,5^{\bullet}$ & $15,5 \pm 1,2^{\star}$ \\
\hline Бігемінія, абс. результат & $0,5 \pm 0,0$ & $16,7 \pm 1,3^{*}$ & $15,9 \pm 1,1^{\bullet}$ & $17,1 \pm 0,8^{\bullet}$ \\
\hline Бігемінія, \% нічних & $1,3 \pm 0,1$ & $10,4 \pm 3,1^{\bullet}$ & $8,1 \pm 2,1^{\star}$ & $10,2 \pm 0,1^{*}$ \\
\hline Тахікардія, абс. результат & $0,0 \pm 0,0$ & $23,0 \pm 1,1$ & $24,2 \pm 0,7$ & $25,1 \pm 0,8$ \\
\hline Тахікардія, \% нічних & $0,0 \pm 0,0$ & $12,0 \pm 0,8$ & $12,8 \pm 0,9$ & $12,7 \pm 0,9$ \\
\hline
\end{tabular}

Примітка $1 . \downarrow$ - різницю показника із групою здорових статистично доведено $(\mathrm{p}<0,05)$.

льованість астми впливає на тимчасову дезадаптацію серцевого функціоналу не тільки через патогенез самого захворювання (постійний бронхоспазм, наявність нападів і т.д.), але і через негативний вплив базисної терапії захворювання (глюкокортикоїди, бронходилятатори).

При легкому перебігу астми ніяких достовірних порушень з боку функціонального стану серця не виявлено, що свідчить про повну реа- 
Таблиця 5

\section{Результати добового моніторингу ЕКГ у хворих на БА із тяжким не контрольованим перебігом (M $\pm \mathbf{m})$}

\begin{tabular}{|c|c|c|c|c|}
\hline Показники & Здорові & Візит I & Візит III & Візит IV \\
\hline 1 & 2 & 3 & 4 & 5 \\
\hline Мінімальна ЧСС за добу & $72,3 \pm 3,3$ & $76,8 \pm 3,2^{*}$ & $79,3 \pm 3,5^{\circ}$ & $87,9 \pm 3,1^{\bullet} \#$ \\
\hline Середня ЧСС за добу & $73,5 \pm 2,9$ & $78,3 \pm 2,5$ & $82,5 \pm 2,5^{\circ}$ & $89,4 \pm 2,7^{*} \#$ \\
\hline Максимальна ЧСС за добу & $89,1 \pm 3,3$ & $98,2 \pm 3,5^{\circ}$ & $99,8 \pm 2,8^{\star}$ & $120,5 \pm 3,6^{\bullet} \#$ \\
\hline Мінімальна ЧСС за день & $65,2 \pm 3,4$ & $68,3 \pm 3,2$ & $75,7 \pm 2,5^{\star}$ & $85,8 \pm 2,9^{*} \#$ \\
\hline Середня ЧСС за день & $77,7 \pm 3,0$ & $75,3 \pm 2,4$ & $82,4 \pm 2,8$ & $96,1 \pm 2,8^{*} \#$ \\
\hline Максимальна ЧСС за день & $99,1 \pm 3,3$ & $111,3 \pm 3,0^{*}$ & $122,7 \pm 3,5^{*}$ & $138,5 \pm 2,3^{\star} \#$ \\
\hline Мінімальна ЧСС за ніч & $68,9 \pm 3,4$ & $65,4 \pm 2,1$ & $67,5 \pm 2,2$ & $88,4 \pm 1,8^{\star} \#$ \\
\hline Середня ЧСС за ніч & $63,7 \pm 2,8$ & $68,4 \pm 2,3$ & $72,3 \pm 2,4$ & $75,3 \pm 2,2^{\bullet} \#$ \\
\hline Максимальна ЧСС за ніч & $73,5 \pm 2,7$ & $76,7 \pm 2,3$ & $78,9 \pm 2,4$ & $86,8 \pm 3,5^{\bullet} \#$ \\
\hline \multicolumn{5}{|c|}{ Шлуночкові результати } \\
\hline Скорочення, абс. результат & $72,5 \pm 96,5$ & $148,4 \pm 5,1^{\bullet}$ & $173,2 \pm 6,5^{\circ}$ & $183,5 \pm 7,1^{\bullet} \#$ \\
\hline Скорочення, \% нічних & $18,7 \pm 4,3$ & $27,9 \pm 3,2$ & $32,4 \pm 3,2^{+}$ & $31,4 \pm 2,8^{\bullet} \#$ \\
\hline $\begin{array}{l}\text { Шлуночкові екстрасистоли, } \\
\text { абс результат }\end{array}$ & $12,8 \pm 0,6$ & $83,1 \pm 8,2^{\bullet}$ & $98,7 \pm 8,2^{\bullet}$ & $128,2 \pm 8,5^{\bullet} \#$ \\
\hline $\begin{array}{l}\text { Шлуночкові екстрасистоли, } \\
\text { \% нічних }\end{array}$ & $10,1 \pm 2,3$ & $32,5 \pm 3,6^{\circ}$ & $42,3 \pm 4,5^{\bullet}$ & $43,2 \pm 2,1^{\bullet} \#$ \\
\hline Парні, абс. результат & $2,5 \pm 0,2$ & $3,8 \pm 0,9$ & $4,3 \pm 2,2^{\bullet}$ & $4,5 \pm 1,8^{\star}$ \\
\hline Парні, \% нічних & $3,1 \pm 0,8$ & $20,7 \pm 2,5^{\circ}$ & $29,0 \pm 3,2^{+}$ & $26,5 \pm 2,9^{*}$ \\
\hline Пробіжки, абс. результат & $0,2 \pm 0,1$ & $17,6 \pm 0,2^{\star}$ & $18,3 \pm 0,1^{\bullet}$ & $18,2 \pm 0,8^{\star}$ \\
\hline Пробіжки, \% нічних & $0,0 \pm 0,0$ & $15,7 \pm 2,3^{*}$ & $15,8 \pm 2,5^{\star}$ & $15,5 \pm 1,2^{\star}$ \\
\hline Бігемінія, абс. результат & $0,5 \pm 0,0$ & $16,7 \pm 1,3^{*}$ & $15,9 \pm 1,1^{+}$ & $17,1 \pm 0,8^{\bullet}$ \\
\hline Бігемінія, \% нічних & $1,3 \pm 0,1$ & $10,4 \pm 3,1^{\star}$ & $8,1 \pm 2,1^{\star}$ & $10,2 \pm 0,1^{\star}$ \\
\hline Тахікардія, абс. результат & $0,0 \pm 0,0$ & $23,0 \pm 1,1^{\bullet}$ & $24,2 \pm 0,7^{\star}$ & $25,1 \pm 0,8^{\bullet}$ \\
\hline Тахікардія, \% нічних & $0,0 \pm 0,0$ & $12,0 \pm 0,8^{\star}$ & $12,8 \pm 0,9^{*}$ & $12,7 \pm 0,9^{*}$ \\
\hline
\end{tabular}

Примітка 1. - різницю показника із групою здорових статистично доведено $(\mathrm{p}<0,05)$. Примітка 2. \# - різницю показника із початком спостереження статистично доведено $(\mathrm{p}<0,05)$.

лізацію адаптаційних механізмів серцево-судинної системи для забезпечення повсякденної активності.

При астмі середнього ступеня тяжкості не залежно від контролю перебігу захворювання, запускаються перші дезадаптаційні механізми наростання частоти серцевих скорочень (як вдень, так і вночі). Почастішання шлуночкових екстрасистол, бігемінії і тахікардії в нічний час. 
Однак все це при контрольованому перебігу БА залишається стабільним в часі, тоді як при не контрольованій БА дезадаптація функціонального стану серця достовірно наростає.

При тяжкому перебігу бронхіальної астми у функціональному стані серця повністю реалізовують себе дезадаптаційні механізми: у відповідь на звичайне щоденне навантаження відбувається високий відсоток тахікардії, шлуночкових екстрасистол (із бігемінією). І тоді як при частково контрольованому важкому перебігу всі вищевказані зміни є більшменш стабільними в часі, то при не контрольованому - відбувається значне прогресування патологічних змін функціонального стану серця.

\section{Список літератури:}

1. Жданов В.Ф. Оценка функционального состояния системы кровообращения у больных бронхиальной астмой. Тр. 7-го Нац. Конгр. по болезням органов дыхания : сб. резюме. Москва, 1997. № 649.

2. Рябова А.Ю. Состояние кардиореспираторной системы у больных бронхиальной астмой на фоне курсовой терапии (глюкокортикоиды, эуфиллин, сальтос) : дис. ... канд. мед. наук. Саратов, 1998. 170 с.

3. Чичерина Е.Н., Шипицына В.В. Состояние сердечно-сосудистой системы у больных бронхиальной астмой различной степени тяжести. Проблемы туберкулеза и болезней легких. 2003. № 8. С. 25-28.

4. Global strategy for asthma management and prevention. National Institutes of Health National Heart \& Lung and Blood Institute. Bethesda, 2014. $146 \mathrm{p}$.

5. Адаптована клінічна настанова, заснована на доказах «Уніфікований клінічний протокол первинної, вторинної (спеціалізованої), третинної (високотехнологічної спеціалізованої) медичної допомоги та медичної реабілітації. Київ : Національна академія медичних наук України, 2016. 190 с.

6. International ERS/ATS Guidelines on Definition, Evaluation, and Treatment of Severe Asthma / K.F. Chung et al. Eur. Respir. J. 2014. Vol. 43. P. 343-373.

7. Global strategy for asthma management and prevention. 2016. URL: http://ginasthma.org/wp-content/uploads/2016/04/GINA-2016-main-report_ tracked.pdf

8. Про затвердження та впровадження медико-технічних документів зі стандартизації медичної допомоги при бронхіальній астмі : наказ МО3 України від 08.10.2013 р. № 868. MO3 України. URL: http://www.moz.gov.ua/ ua/portal/dn_20131008_0868.html

9. Standardisation of spirometry. M.R. Miller [et al.]. Eur. Respir. J. 2005. Vol. 26, pp. $319-338$.

10. Особливості етіології, патогенезу, клінічного перебігу та підходів до лікування тяжкої бронхіальної астми. Ю.І. Фещенко [та ін.]. Астма та алергія. 2017. № 1. С. 7-12. 
11. Добове моніторування артеріального тиску : методичні рекомендації. Інститут кардіології ім. М.Д. Стражеска АМН України. Київ, 2002. 27 с.

12. Амбулаторне ЕКГ-моніторування : рекомендації асоціації кардіологів України. Київ, 2005. 43 с.

13. Сыркин А.Л., Аксельфельд А.С., Чомахидзе П.Ш. Холтеровское мониторирование. ЭКГ: возможности, трудности, ошибки. Москва : Медицинское информационное агенство, 2007. 200 с.

14. Бабич П.Н., Чубенко А.В., Лапач С.Н. Применение современный статистических методов в практике клинических исследований. Сообщение третье. Отношение шансов : понятие, вычисление, интерпретация. Украӥнський медичний часопис. 2005. № 2. С. 113-119.

15. Лапач С.Н., Чубенко А.В., Бабич П.Н. Статистические методы в медикобиологических исследованиях с использованием Excel. Киев : Морион, $2001.320 \mathrm{c}$.

\section{References:}

1. Stus V.P. (2013). Stan krovoobihu parenkhimy nyrok u khvorykh zi stiikym porushenniam urodynamiky [State of renal parenchyma circulation in patients with persistent urodynamic disorders]. Urology. Ukrainian Medical Journal, no 3, pp. 17-19.

2. Stus V.P., Barannik K.S., Shponka I.S., Poslavskaya O.V. (2014). Doslidzhennya modeley odnostoronnikh patolohichnykh protsesiv porushennya mistsevoho nyrkovoho krovoobihu $\mathrm{z}$ metoyu vyznachennya zmin stanu kontralateral'noyi nyrky: imunomorfolohichni aspekty [Investigation of models of unilateral pathological processes of impaired local renal circulation to determine changes in the state of the contralateral kidney: immunomorphological aspects]. Morphology. Ukrainian Medical Journal, vol. 8, no. 4, pp. 43-50.

3. Stus V.P., Barannik K.S. (2015). Kompensatorni mozhlyvosti protylezhnoyi nyrky pry riznykh vydakh odnobichnoho porushennya krovoobihu v eksperymenti [Compensatory possibilities of the opposite kidney in different types of unilateral circulatory disorders in the experiment]. South Ukrainian medical scientific journal, no. 10(10) January, pp. 86-88.

4. Stus V.P., Barannik K.S., Shponka I.S., Poslavskaya O.V. (2015). Porushennya mistsevoho nyrkovoho krovotoku pry modelyuvanni odnostoronnikh patolohichnykh protsesiv u nyrkakh [Disorders of local renal blood flow in the simulation of unilateral pathological processes in the kidneys]. Urology. Ukrainian Medical Journal, no. 3, pp. 29-36.

5. Barannik K.S. (2015). Zminy mikrotsyrkulyatornoho rusla parenkhimy ta nyrkovoho krovotoku shchuriv $\mathrm{v}$ umovakh eksperymental'noyi ishemiyi odniyeyi nyrky [Changes in the microcirculatory bed of the parenchyma and the renal blood flow of rats in experimental ischemia of one kidney]. South Ukrainian medical scientific journal, September 12(12), pp. 15-17.

6. Stus V.P., Sheepdog K.S. (2016). Funktsional'nyy stan i kompensatornoprystosovni mozhlyvosti parnoho orhana - nyrok $\mathrm{v}$ umovakh odnobichnoho urazhennya abo yedynoyi nyrky, shcho zalyshylasya pislya nefrektomiyi (ohlyad 
literatury) [Functional state and compensatory and adaptive capacity of paired organ - kidney in conditions of unilateral lesion or single kidney remaining after nephrectomy (literature review)]. Urology. Ukrainian Medical Journal, no 1(76), pp. 5-16.

7. Stus V.P., Yehalov V.V., Barannik K.S., Kryzhanovsky I.D. (2016). Medykamentozna reabilitatsiya porushen' krovotoku v perioperatsiynomu periodi $\mathrm{u}$ patsiyentiv $\mathrm{z}$ odnobichnym patolohichnym urazhennyam nyrok [Medicinal rehabilitation of blood flow disorders in the perioperative period in patients with unilateral renal pathology]. South Ukrainian Medical Scientific Journal, no. 14 (14), May, pp. 5-8.

8. Barannik K.S. (2016). Kompensatornyye sosudistyye reaktsii u patsiyentov $\mathrm{s}$ odnostoronnim stoykim narusheniyem urodinamiki [Compensatory vascular responses in patients with unilateral persistent urodynamic disorders]. Young Scientist. Ukrainian Medical Journal, no. 8(35), pp. 186-189.

9. Stus V.P., Barannik K.S., Yekhalov V.V., etc. (2016). Medykamentozna korektsiya porushen' krovotoku u patsiyentiv $\mathrm{z}$ odnobichnym patolohichnym urazhennyam nyrok $\mathrm{u}$ perioperatsiynomu periodi [Medication correction of blood flow disorders in patients with unilateral pathological renal injury in the perioperative period]. Urology. Ukrainian Medical Journal, no. 3(78), pp. 89-94.

10. Barannik K.S. (2016). Dynamika zmin nyrkovoho krovotoku pry odnobichnomu urazhenni nyrok $\mathrm{v}$ eksperymenti ta yikh vplyv na stan nyrok $\mathrm{u}$ viddalenomu periodi [Dynamics of changes in renal blood flow in unilateral renal injury in the experiment and their effect on the condition of the kidneys in the distant period]. South Ukrainian medical scientific journal, September 15(15), pp. 13-16.

11. Stus V.P., Barannik K.S., Yehalov V.V., Ukrainian E.P. (2016). Sposib perioperatsiynoyi korektsiyi porushen' krovotoku u patsiyentiv $\mathrm{z}$ odnobichnym patolohichnym urazhennyam nyrok [The method of perioperative correction of blood flow disorders in patients with unilateral renal pathology]. Proceedings of the Scientific and Practical Conference "Urology, Andrology, Nephrology - 2016" / Ed. V.M. Forest, I.M. Anthony and others. Kharkiv. Ukrainian Medical Journal, pp. 211-212.

12. Stus V.P., Barannik K.S. (2016). Vyvchennya stanu krovotoku nyrok za stvorenoyu novym sposobom eksperymental'noyi modeli tryvaloyi ishemiyi nyrky [The study of the state of the blood flow of the kidneys by a new way of experimental model of long-term ischemia of the kidney]. Proceedings of the Scientific and Practical Conference "Urology, Andrology, Nephrology" - 2016 "/ Ed. V.M. Forest, I.M. Anthony and others. Kharkiv. Ukrainian Medical Journal, pp. 305-306.

13. Stus V.P., Barannik K.S., Shponka I.S., Poslavskaya A.V. (2015). Narusheniye mestnogo pochechnogo krovotoka pri modelirovanii odnostoronnikh patologicheskikh protsessov v pochkakh [Disruption of local renal blood flow in the simulation of unilateral pathological processes in the kidney]. Urology. Ukrainian Medical Journal, no. 2, p. 84.

14. Barannik K.S. (2015). Stan nyrkovoho krovotoku v umovakh eksperymental'noyi ishemiyi odniyeyi nyrky [The state of renal blood flow in experimental ischemia of one kidney]. Ukrainian Scientific and Medical Youth Journal. Special issue, no. 3(90), p. 96. 
15. Barannik K.S. (2014). Hemodynamika parenkhimy nyrok u khvorykh iz odnobichnym porushennyam urodynamiky [Changes in blood circulation in the renal parenchyma in experimental ischemia of one of them]. Proceedings of the International Scientific and Practical Conference "Pharmaceutical and Medical Sciences: Topical Issues" (Dnipropetrovsk, May 16-17, 2014) Ukrainian Medical Journal, pp. 40-42.

16. Stus V.P., Barannik K.S., Trofimov M.V. (2014). Medicamentous correction of kidney blood-groove and perioperation of the period. The 18th European Society of Surgery (ESS) Meeting \& The 17th Spring Annual Congress of the Lebanese Society for General Surgery (LSGS), p. 53.

17. Barannik K.S. (2016). Morfolohichna ta imunohistokhimichna kharakterystyka nyrok shchuriv iz odnobichnym stiykym porushennyam krovoobihu [Morphological and immunohistochemical characteristics of rat kidneys with unilateral persistent circulatory disorders]. Theoretical and practical aspects of the development of modern medicine. Collection of abstracts of scientific works of participants of the international scientific-practical conference (Lviv, June 24-25, 2016). Lviv: NGO "Lviv Medical Community", pp. 20-24. 